\title{
Urgensi Omnibus Law (Undang-Undang Cipta Kerja) Terhadap Hak Masyarakat Adat di Wilayah Pesisir
}

\section{Dolfries J Neununy}

Sekolah Tinggi Ilmu Ekonomi, Saumlaki, Indonesia

@ : dolfriesneununi86@gmail.com

: $X X X X X X X X X X X$

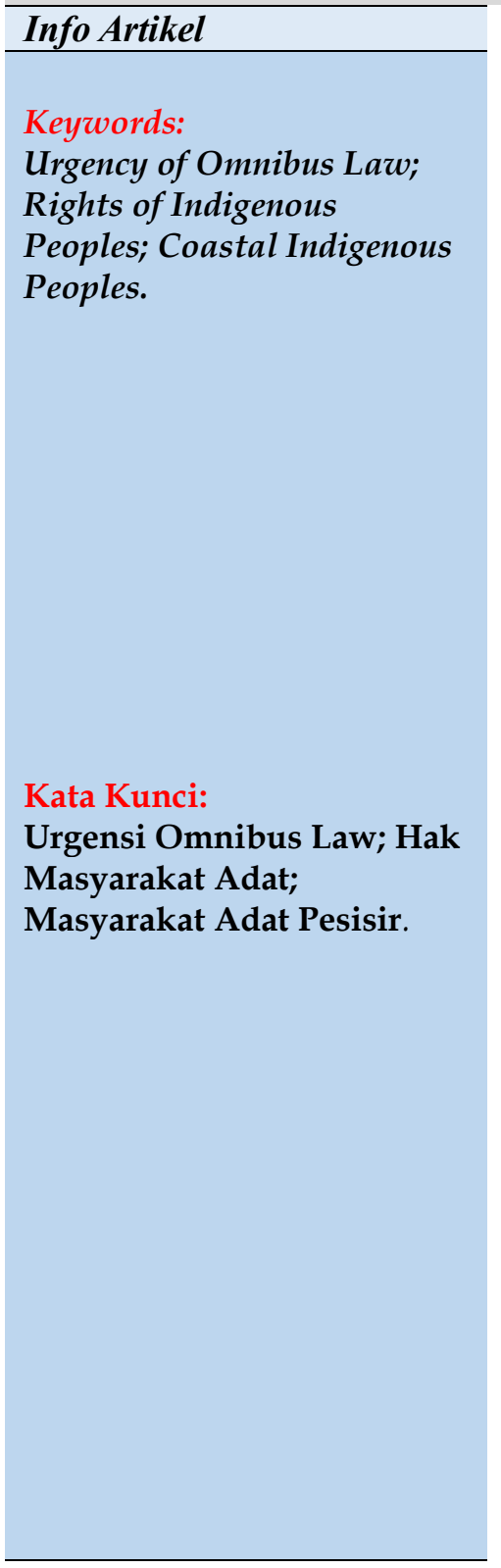

\begin{abstract}
Introductioan: Substantial application of the Omnibus Law (Cipta Kerja) for the rights of indigenous peoples in coastal areas.

Purposes of the Research: Reviewing and analyzing the impact of the Copyright Act on indigenous peoples in coastal areas.

Methods of the Research: The research was conducted through normative legal research with a political approach to review and analyze legislation or other legal materials related to the Urgency of Omnibus Law on the Rights of Indigenous Peoples in coastal areas.

Results of the Research: The presence of the Omnisbus Law will have a positive impact on the community from the aspect of legal knowledge that people belonging to the scientific community can understand the purpose of the government to implement the Omnisbus Law but from the other side the ordinary people who are in coastal areas and remote rural areas do not understand well the application of the Omnisbus Law so that protection is important.
\end{abstract}

Abstrak
Latar Belakang: Penerapan undang-undang Omnibus Law (Cipta
Kerja) hak masyarakat adat di wilayah pesisir yang secara
substansial.
Tujuan Penelitian: Mengkaji dan menganalisis tentang dampak
UU Cipta Kerja terhadap masyarakat adat diwilayah pesisir.
Metode Penelitian: Penelitian dilakukan melalui penelitian
hukum normatif dengan pendekatan politik hukum untuk
mengkaji dan menganalisis peraturan perundang-undangan
atau bahan hukum lain yang berkaitan dengan Urgensi
Omnibus Law Terhadap Hak Masyarakat Adat di wilayah Pesisir.
Hasil Penelitian: Kehadiran UU Cipta Kerja (Omnisbus Law) ini
akan memberikan dampak positif bagi masyarakat dari aspek
pengetahuan hukum bahwa masyarakat yang tergolong
masyarakat ilmiah dapat memahai tujuan dari pada pemerintah
untuk menerapkan UU Cipta Kerja (Omnisbus Law) akan tetapi dari
sisi lain para masyarakat awam yang berada pada wilayah pesisir
dan terpelosok pedesaan tidak memahami secara baik terhadap
penerapan UU Cipta Kerja (Omnisbus Law) sehingga perlindungan
itu penting.

\section{A. PENDAHULUAN}

Undang-undang Cipta Kerja yang selanjutnya disingkat UU Cipta Kerja merupakan bagian dari dinamika regulasi dan Parlemen dalam system 
ketatanegaraan Indonesia yang lazim. UU Cipta Kerja yang bermetode Omnibus Law sampai saat ini masih menjadi perbincangan dan diskursus yang sangat hangat pada berbagai kalangan dengan analis social, hukum, dan lain-lain, dalam penulisan ini penulis mengkaji dan menganalisis dari aspek yang berbedah dari sebelumnya yaitu dengan melihat bagaimana hubungan atau relasi UU Cipta Kerja dengan masyarakat Adat yang berada pada wilayah pesisir terkhususnya masyarakat yang berada pada daerah kepulauan yang sudah ada sebelum bangsa ini merdeka dan memiliki hak-hak pengelolaan dan pengembangan Sumber daya alam yang dimiliki.

Pembentukan produk hukum yang baik dan dapat diterima oleh masyarakat tentunya harus melalui proses pentahapan dan berbagai asas hukum yang memberikan batasan sebagaimana diatur dalam UU Nomor 12 Tahun 2011 tentang Pembentukan Peraturan Perundang-Undangan ${ }^{1}$. Kaitanya dengan pembentukan Peraturan Perundang undangan, ditegaskan oleh Burkhard Kremes ${ }^{2}$ bahwa dalam pembentukan Peraturan Perundang undangan harus didasarkan pada asas-asas pembentukan peraturan perundang-undangan yang meliputi, Susunan peraturan (Form der regelung), Metode pembentukan peraturan (Metode der ausorbeitung der regelung), Bentuk dan isi peraturan (Inhalt der regelung), Prosedur dan proses pembentukan peraturan (Verforen der Ausarbeitung der regelung). Maksudnya adalah agar produk hukum yang dibentuk oleh lembaga yang berwewenang ini dapat memiliki daya mengikat dan daya laku dalam masyarakat sesuai dengan kebutuhan masyarakat dan kebutuhan pemerintah untuk mensejahterakan masyarakat terkhusnya masyarakat adat yang ada pada wilayah pesisir.

Problematika dari UU Cipta Lapangan Kerja yang bermetode Omnibus law ini adalah kemudahan perizinan, menghapus dan mengubah beberapa pasal dan ayat yang ada pada UU Nomor 26 tahun 2007 tentang Penataan Ruang, UU Nomor 27 Tahun 2007 tentang Pengelolaan Wilayah Pesisir dan Pulau-Pulau Kecil, UU Nomor 32 tahun 2014 tentang Kelautan dan UU Nomor 4 Tahun 2011 tentang Informasi Geospasial yang pada intinya adalah pengalihan sebagian besar kewenangan pemerintah daerah baik Provinsi, Kabupaten dan kota pada satu pintu yaitu pemerintah pusat. UU Cipta Lapangan Kerja yang bermetode Omnibus law ini dengan 1028 halam setelah disahkan secara otomatis UU Nomor 26 tahun 2007 tentang Penataan Ruang. Pasal 1 angka 23, angka 24, angka 29, dan angka 30 tidak lagi berlaku atau dinyatakan Pasal tersebut telah di hapus sehingga tidak ada lagi wilayah-wilayah strategis Pedesaan, Kabupaten mapun Provinsi yang berkaitan dengan Kawasan strategis ekonomi, sosial, budaya, atau lingkungan. Lebih urgen dari UU Cipta Kerja ini adalah hak Masyarakat Adat berkaitan dengan hak pengelolaan sumberdaya alam.

Kehidupan masyarakat hukum adat pada wilayah pesisir masih petergantung dari alam artinya mata pencaharian mereka disesuaikan dengan musim itu pertanda bahwa pola kehidupan mereka masih sangat tradisional sehingga negara sebagai organisasi yang besar mampu meberikan rasa nyaman kepada masyarakat adat yang mendiami wilayah pesisir tertuang dalam Undang-Undang Nomor 1 tahun 2014

5.

1 UU Nomor 12 Tahun 2011 tentang Pembentukan Peraturan Perundang-Undangan, Bab II, Pasal

2 H. A. Muin Fahmal, Peran Asas-Asas Umum Pemerintahan Yang Layak Dalam Mewujudkan Pemerintahan Yang Bersih, (Yogyakarta: UII Press, 2006), h. 62-63. 
tentang Wilayah Pesisir didalamnya menjelaskan bahwa hak-hak masyarakat adat pesisir wajib dilindungi oleh negara kata dilindungi ini menunjukan sebuah kewajiban untuk dilaksanakan.

Kehadiran Omnibus Law dapat memberikan suatu titik terang kepada keberadaan masyarakat hukum adat karena merujuk Pasal 1 butir f UU No.41 Tahun 1999 berbunyi hutan negara yang berada dalam wilayah masyarakat hukum adat sesuai dengan putusan MK No 35/PUU-X/2012 berbunyi hutan adat adalah hutan yang berada dalam wilayah masyarakat hukum adat kalimat ini sering kali bertentangan dengan kebijakan negara dalam mengelola hutan karena dalam tahapan perkembangan indonesia sebagai negara berkembang pemerintahan Orde Lama dan Orde Baru, dan Orde Reformasi yang mengindikasikan kemerdekaan masyarakat hukum adat tampak semakin terpinggirkan. Sebutan 'peladang liar', 'penebang liar', 'suku terasing','masyarakat terasing' dan sejenisnya menujukkan nasib masyarakat hukum adat terpinggirkan sampai pada meminta perlindungan hukum kepada negara dengan alas an yang logis bahwa hutan dan tanah mereka telah dikuasi oleh pihak perusahan yang seringkali mengatasnamakan negara untuk kepentingan bisnis dan telah mengantonggi ijin resmi dari kementrian kehutanan untuk pelaksanaan obperasi perusahan.

Perkembangan hukum dan masyarakat Indonesia berubah seiring dengan perkembangan bukan saja tuntutan sosial, budaya, ekonomi dan politik, tetapi juga sistem hukum nasional turut berubah pula, Pasal 1 butir 31 UU tahun 2009 berbunyi kelompok masyarakat yang secara turun temurun bermukim diwilyah geografis tertentu karena adanya ikatan pada asal-usul leluhur, adanya hubungan yang kuat dengan lingkungan hidup. serta adanya sistem nilai yang menentukan pranata ekonomi, politik, sosial dan hukum.

Masyarakat adat yang mendiami wilayah pesisir seringkali diperhadapkan dengan kibijakan pemerintah untuk pengembangan bisnis berskala besar seperti pemberian ijin kepada para investor untuk pengelolaan sumberdaya alam baik didarat maupun dilaut sehingga terjadi benturan sampai pada konflik dengan masyarakat adat karena wilayah petuanan adat masyarakat adat dikuasai dengan cara paksa karena perusahan telah mengantongi ijin resmi dari pemerintah pusat untuk melakukan ekplorasi dan ekploitasi perusahan karena kewenangan yang begitu besar yang dimiliki oleh pemerintah lewat Pasal 33 ayat (3) UUD 1945, khususnya frasa" untuk sebesar-besar kemakmuran rayat, sudah tentunya pemerintah harus mengelola kemampuan sumdaya alam untuk kemakmuran masyarakat.

UUPA Pasal 41 berbunyi bahwa hak untuk menggunakan dan/atau memungut hasil dari tanah yang dikuasai langsung oleh negara atau tanah milik orang lain, yang memberi wewenang dan kewajiban yang ditentukan dalam keputusan pemberiannya oleh pejabat yang berwenang memberikannya atau dalam perjanjian pengolahan tanah, segala sesuatu asal tidak bertentangan dengan jiwa dan ketentuan UU ini. dalam Pasal 28 ayat (1) UUPA berbunyi hak untuk mengusahakan tanah yang dikuasai oleh negara dalam jangka waktu tertentu guna perusahaan pertanian, perikanan atau peternakan Hak Pengusahaan Perairan Pesisir atau HP-3 yang merupakan hak atas bagian-bagian tertentu dari perairan pesisir untuk usaha kelautan dan perikanan, serta usaha lain yang terkait dengan pemanfaatan Sumber Daya Pesisir 
dan Pulau-pulau kecil yang mencakup atas permukaan laut dan kolom air sampai dengan permukaan dasar laut pada batas keluasan tertentu hilang dan tidak ada lagi hak masyarakat adat dalam upaya Pengusahaan Perairan Pesisir di wilayah pesisir.

\section{B. METODE PENELITIAN}

Penelitian dilakukan melalui penelitian hukum normatif dengan pendekatan politik hukum untuk mengkaji dan menganalisis peraturan perundang-undangan atau bahan hukum lain yang berkaitan dengan Urgensi Omnibus Law Terhadap Hak Masyarakat Adat di wilayah Pesisir. Penelitian hukum ini dilakukan melalui pendekatan peraturan perundang-undangan (statutory approach) ${ }^{3}$. Pendekatan politik hukum digunakan dalam penelitian ini untuk mewujudkan peraturan-peraturan yang baik dan dapat menjawab kebutuhan masyarakat Adat sesuai keadaan dan situasi terkhususnya Hak Masyarakat Adat di wilayah Pesisir. Padmo Wahjono ${ }^{4}$ berpandangan, politik hukum adalah kebijakan dasar yang menentukan arah, bentuk, maupun isi hukum yang akan dibentuk. Menurut Satjipto Rahardjo ${ }^{5}$, politik hukum merupakan aktivitas memilih dan mekanisme yang digunakan dalam rangka mencapai tujuan sosial dan hukum tertentu dalam masyarakat. Sedangkan Soedarto ${ }^{6}$ menjelaskan bahwa politik hukum merupakan kebijakan negara melalui badan-badan negara yang berwenang untuk menetapkan peraturan-peraturan yang dikehendaki yang diperkirakan dan yang digunakan untuk mengekspresikan apa yang terkandung dalam masyarakat dan untuk mencapai tujuan yang menjadi cita-cita.

\section{HASIL DAN PEMBAHASAN}

\section{Perlindungan Terhadap Masyarakat Adat}

Masyarakat Adat yang selanjutnya disebut Masyarakat Adat merupakan suatu kelompok yang hidup secara turun temurun di wilayah geografis tertentu dan memiliki asal usul leluhur dan/atau kesamaan tempat tinggal, identitas budaya, hukum adat, serta hubungan yang kuat dengan tanah dan lingkungan hidup, mempunyai sistem nilai untuk menentukan pranata ekonomi, politik, sosial, budaya, dan hukum, corak identitas masyarakat adat yang heterogen seperti ini tentunya harus dilindungi oleh negara. Masyarakat adat ${ }^{7}$ yang berada di wilayah pesisir tentunya merupakan kelompok Masyarakat Pesisir yang secara turun-temurun bermukim di wilayah geografis tertentu karena adanya ikatan pada asal-usul leluhur, memiliki hubungan yang kuat dengan Sumber Daya Pesisir dan Pulau - Pulau Kecil, serta memiliki sistem nilai yang menentukan pranata ekonomi, politik, sosial, dan hukum.

${ }^{3}$ Johni Ibrahim, Teori Dan Metodologi Penelitian Hukum Normatif (Malang: Bayumedia Publishing, 2007), h. 300.

${ }^{4}$ Mahfud MD, Politik Hukum Di Indonesia (Jakarta: Rajawali Pers, 2010), h. 1.

${ }^{5}$ Mahfud MD, Membangun Politik Hukum, Menegakkan Konstitusi (Jakarta: Rajawali Pers, 2011), h. 15.

${ }^{6}$ Ibid.,h. 14.

7 BAB 1 Pasal 1 Angka (33), UU NO. 27 Tahun 2007 Tentang Pengelolaan Wilayah Pesisir dan Pulau- Pulau Kecil. 
Perlindungan oleh negara kepada Masyarakat Adat merupakan upaya untuk menjamin dan melindungi Masyarakat Adat beserta haknya agar dapat hidup tumbuh dan berkembang sesuai dengan harkat dan martabat kemanusiannya. Letak atau esensi dari hukum adalah untuk melindungi kepentingan rakyat dengan memberikan keadilan, kebebasan menentukan pilihan, perlakuan yang adil, perlakuan yang manusiawi, serta memberikan hak-hak masyarakat untuk memperoleh kesejahteraan dan pekerjaan yang layak, termasuk yang bermuatan penegakan hukum. Apabila dalam penyelenggara kekuasaan mengimplementasikan tugas yang digariskan oleh hukum ini berarti menyelenggarakan tujuan ideal yang sudah melekat dalam diri negara hukum seperti menjaga dan melindungi kehidupan manusia harapan hukum telah terpenuh ${ }^{8}$. Masyarakat adat yang merupakan sekumpulan orang yang memiliki batas tertentu pada suatu wilayah dan tentu memilik berbagai nilai social yang harus dilindungi oleh negara melalui hukum yang dibentuk. Sehubungan dengan perlindungan hukum, CST Kansil ${ }^{9}$ berpendapat bahwa "Perlindungan hukum adalah penyempitan arti dari perlindungan, dalam hal ini hanya perlindungan oleh hukum saja. Perlindungan yang diberikan oleh hukum, terkait pula dengan adanya hak dan kewajiban, dalam hal ini yang dimiliki oleh manusia sebagai subyek hukum dalam interaksinya dengan sesama manusia serta lingkungannya. Sebagai subyek hukum, manusia memiliki hak dan kewajiban untuk melakukan suatu tindakan hukum yang dalam pelaksanaan tindakan hukum tersebut adanya perlindungan oleh hukum

Perlindungan hukum tidak semata untuk kepentingan rakyat tanpa melihat kebutuhan pemerintah yang secara aktual untuk kesejahteraan masyarakat namun perlindungan hukum terhadap masyarakat dilakukan agar terjalin hubungan yang harmonis antara masyarakat dengan pemerintah. Sehubungan dengan perlindungan hukum dan penciptaan hubungan harmonis antara masyarakat/warga negara dengan pemerintah, ditegaskan oleh Ridwan HR 10, bahwa "Agar hubungan hukum antar subjek hukum itu berjalan secara harmonis, seimbang dan adil, dalam arti setiap subjek hukum mendapatkan apa yang menjadi haknya dan menjalankan kewajiban yang dibebankan kepadanya, maka hukum tampil sebagai aturan main dalam mengatur hubungan-hubungan hukum tersebut. Hukum tampil sebagai suatu instrumen yang memberikan perlindungan hukum yang aktual".

Perlindungan terhadap masyarakat adat dalam konstitusi Republik Indonesia merupakan pengakuan yang mutlak dan absolut untuk dilindungi dan diberikan kekuasaan sebagai masyarakat adat yang mampu tumbuh dan berkembang sesuai dengan perkembangan zaman. Landasan konstitusional terhadap masyarakat Adat sebelum amandemen yaitu Pasal 18 UUD 1945 yang dalam penjelasannya menegaskan, "Dalam territoir Indonesia terdapat lebih kurang 250 Zelfbesturende landschappen (daerah swapraja, yaitu wilayah yang dikuasai raja yang mengakui kekuasaan dan kedaulatan pemerintah Belanda melalui perjanjian politik verklaring) dan Volksgemeenshappen (tidak ada penjelasan dalam UUD 1945, hanya memberikan

8 Roscoe Pound, An Introduction to the Philosophy of Law, Terjemahan (Jakarta: Bhatara Niaga Media, 1996), h. 56.

9 C.S.T Kansil, Pengantar Ilmu Hukum Dan Tata Hukum Indonesia (Jakarta: Balai Pustaka, 1980), h. 102.

10 Ridwan HR, Hukum Administrasi Negara (Jakarta: Raja Grafindo Persada, 2018), h. 265. 
contoh pada beberapa daerah, seperti Desa di Jawa dan Bali, negeri di Minangkabau, dusun, dan marga di Palembang, dan sebagainya). Daerah-daerah itu mempunyai susunan asli, dan oleh karenanya dapat dianggap sebagai daerah yang bersifat istimewa.

Dengan perkembangan dinamika politik hukum nasional maka ditegaskan secara komprehensif dan eksplisit pada hasil amandemen UUD 1945 saat ini yang dinormakan pada ketentuan Pasal 18B ayat (2) bahwa "Negara mengakui dan menghormati kesatuan-kesatuan masyarakat hukum adat beserta hak-hak tradisionalnya sepanjang masih hidup dan sesuai dengan perkembangan masyarakat dan prinsip negara kesatuan Republik Indonesia, yang diatur dalam undang-undang". Pengakuan secara konstitusional sebagaiaman yang ditegaskan pada ketentuan Pasal 18B ayat (2) UUD 1945 Memberikan suatu ligitimasi yang sangat determinan kepada masyarakat hukum adat yang berda pada suatu wilayah negara kesatuan Republik Indonesia. Pengakuan secara konstitusional ini tentu sangat berkonsekuensi jika hakhak masyarakat dipersempit (Imperatif) oleh berbagai peraturan Perundang-undang oraganik.

\section{Hak-Hak Masyarakat Adat}

Hak konstitusional merupakan hak yang dijamin oleh konstitusi sehingga organ negara yang menjalankan fungsi dan kewenangannya wajib untuk melindungi hak konstitusional setiap orang, warga negara dan kelompok masyarakat atau masyarakat adat yang memiliki hak konstitusiol tersebut. Kaitannya dengan hak konstitusional, Jimly Asshidiqie, 11 menjelaskan bahwa Hak Konstitusional (constitutional rights) dapat diartikan sebagai hak asasi manusia yang telah tercantum dengan tegas dalam UUD Tahun 1945, sehingga juga telah resmi menjadi hak konstitusional setiap warga negara. Perbedaan antara hak konstitusional dengan hak legal, bahwa hak konstitusional adalah hak-hak yang dijamin di dalam dan oleh UUD Tahun 1945, sedangkan hak-hak hukum (legal right) timbul berdasarkan jaminan Undang-Undang dan Peraturan Perundang-undangan di bawahnya (subordinate legislations).

Hak-hak konstitusional dan kebebasan tersebut ada yang tercantum dalam UUD Tahun 1945 dan ada pula yang tercantum hanya dalam undang-undang tetapi memiliki kualitas yang sama pentingnya secara konstitusional sehingga dapat disebut memiliki "constitutional importance" yang sama dengan yang disebut eksplisit dalam UUD Tahun 1945 12. Sesuai dengan prinsip kontrak sosial (social contract), maka setiap hak yang terkait dengan warga negara dengan sendiri bertimbal-balik dengan kewajiban negara untuk memenuhinya dengan prinsip untuk melindungi dari berbagai ancaman dan tidak boleh mengurangi sedikitpun baik dengan kebijakan pemerintah maupun dengan membuat regulasi yang mengurangi atau mengamputasikan hak-hak konstitusi warga negara terkhususnya masyarakta Adat yang berada di wilayah pesisir.

Hak-hak masyarakat adat dikonversikan menjadi beberapa bagian jika kita melihat berbagai produk hukum dan regulasi yang ada. Hak masyarakat adat pada

11 Jimly Asshiddiqie, Pengantar Ilmu Hukum Tata Negara (Jakarta: Rajawali Pers, 2014), h. 134.

12 Jimly Asshiddiqie, Hukum Tata Negara Dan Pilar Demokrasi, Serpihan Pemikiran Hukum Dan HAM (Jakarta: Konstitusi Press, 2005), h. 224. 
wilayah darat dapat kita amati Putusan Nomor 35/PUU-X/2012 yang menetapkan hutan adat oleh negara kepada masyarakat adat, implementasi dari Putusan MK tersebut maka dibentuklah beberapa produk hukum untuk menjabarkan putusan MK ini dengan dikeluarkannya Peraturan Menteri (PerMen) Kehutanan No. P.62/Menhut-II/2013 tentang Perubahan Atas PerMen Kehutanan No. P.44/MENHUT-II/ 2012 tentang Pengukuhan Kawasan Hutan, UU No. 6 Tahun 2014 tentang Desa, Permendagri No. 52 Tahun 2014 tentang Pedoman Pengakuan dan Perlindungan Masyarakat Hukum Adat, serta PerMen Agraria dan Tata Ruang (ATR) No. 10 Tahun 2016 tentang Tata Cara Penetapan Hak Komunal atas Tanah Masyarakat Hukum Adat dan Masyarakat yang Berada dalam Kawasan Tertentu.

Hak-hak masyarakat adat yang perlu untuk diketahui juga bahwa dalam hal Pengelolaan pertambangan di Indonesia menurut UU No. 22 Tahun 2001 tentang Minyak dan Gas Bumi, serta UU No. 4 Tahun 2009 tentang Pertambangan Mineral dan Batubara. Di dalam UU No. 2 Tahun 2001 tentang Minyak dan Gas Bumi (UU Migas) diatur mengenai perlindungan terhadap masyarakat adat, seperti yang terdapat di dalam Pasal 11, Pasal 33 dan Pasal 34 UU Migas. Di dalam Pasal 11 UU Migas yang mengatur mengenai Kontrak Kerja Sama (KKS) dalam usaha hulu migas ditentukan bahwa di dalam KKS tersebut harus membuat beberapa ketentuan pokok, salah satunya adalah mengenai pengembangan masyarakat sekitarnya dan jaminan hakhak masyarakat adat. Dengan ketentuan ini, maka semua KKS yang dipegang oleh perusahaan Migas harus berisi tentang bagaimana perlindungan terhadap hak masyarakat adat apabila wilayah konsesi dari perusahaan Migas tersebut di atas atau berada di dekat wilayah kehidupan masyarakat adat. Hak-hak masyarakat Adat diwilayah pesisir dapat kita amati pada UU Nomor 27 Tahun 2007 tentang Pengelolaan Wilayah Pesisir dan Pulau-Pulau Kecil yang telah di ubah dengan UU Nomor 1 Tahun 2014.

\section{Implikasi Hukum Penerapan UU Cipta Kerja (Omnibus Law) Terhadap Hak- hak Masyarakat Adat}

Pembentukan peraturan perundang-undangan tentunya harus melihat berbagai faktor yang sering dalam prakteknya akan mempengaruhi faktor-faktor penegakan hukum itu sendiri, problematik inilah merupakan fungsi dari badan berwenang untuk mampu mendeteksi kebutuhan masyarakat dan iklim social agar produk hukum yang terbentuk merupakan produk yang benar-benar responsive dan progresif sesuai kebutuhan masyarakat dan perkembangan yang ada. Menurut Soerjono Soekanto ${ }^{13}$, faktor-faktor penegakan hukum tersebut merupakan pengembangan dari pendapat Lawrence M Friedman dengan teorinya Sistem Hukum (Legal System) yang terdiri: Substansi hukum (legal substance), Struktur hukum (legal structure), Budaya hukum (legal culture).

Dalam penulisan ini penulis lebih menekankan pada Substansi hukum (legal substance) dengan melihat bahwa apakah pembentukan RUU Cipta Kerja yang dalam substansinya telah megatur dan melindungan hak-hak masyarakat Adat atau sebaliknya telah mengamputasikan hak-hak masyarakat adat itu sendiri terkhususnya

13 Soeryono Soekanto, Faktor-Faktor Yang Mempengaruhi Penegakan Hukum (Jakarta: Raja Grafindo Persada, 2008), h. 32. 
masyarakat adat di wilayah pesisir. Substansi hukum (legal substance) atau isi dari UU Cipta Kerja ini yang dapat diamati. Keberadaan masyarakat hukum adat mesti dilindungi oleh negara sehingga bentuk pengakuan terhadap hak-hak untuk kepemilikan mereka mesti ada pengakuan oleh negara.

\section{Upaya Mengatasi Dampak Penerapan UU Cipta Kerja (Omnibus Law)}

Dalam rangka untuk mengatasi dampak penerapan UU Cipta Kerja (Omnisbus Law) kepada masyarakat indonesia sudah tentu menjadi tanggungjawab Negara karena kehadiran dari UU Cipta Kerja (Omnisbus Law) ini sangat kontraversial bahkan terjadi penolakan dari berbagai ormas, aktifis, buruh serta pengusaha dan sebagaian masyarakat yang berada diberbagai Kabupaten Kota dan Provinsi di Indonesia dengan alasan yang logis bahwa penerapan UU Cipta Kerja (Omnisbus Law) akan mempengaruhi kehidupan masyarakat dari berbagai bidang mulai dari bidang hukum, social budaya serta ekonomi karena banyak masyarakat tidak memahami secara pasti dari substansi penerapan UU Cipta Kerja (Omnisbus Law). Kehadiran UU Cipta Kerja (Omnisbus Law) ini akan memberikan dampak positif bagi masyarakat dari aspek pengetahuan hukum bahwa masyarakat yang tergolong masyarakat ilmiah dapat memahai tujuan dari pada pemerintah untuk menerapkan UU Cipta Kerja (Omnisbus Law) akan tetapi dari sisi lain para masyarakat awam yang berada pada wilayah pesisir dan terpelosok pedesaan tidak memahami secara baik terhadap penerapan UU Cipta Kerja (Omnisbus Law) ini sehingga tugas pemerintah baik eksekutif maupun yudikatif sebagai pemegang dalil kekuasaan harus memberikan sosialisasi terhadap penerapan UU Cipta Kerja (Omnisbus Law) serta dampak positif yang akan dirasakan oleh masyarakat indonesia dan argumentasi hukum bahwa UU Cipta Kerja (Omnisbus Law) akan memberikan keberadaan masyarakat hukum adat di Indonesia sudah ada jauh sebelum negara ini merdeka sudah tentu menjadi tanggungjawab negara untuk melindunggi masyarakat hukum adat. Merujuk pada Pasal 18B ayat 2 UUD 1945 bahwa negara mengakui dan menghormati kesatuankesatuan masyarakat hukum adat berserta hak-hak tradisional sepanjang masih hidup dan sesuai dengan perkembangan masyarakat dan prinsip negara kesatuan republik indonesia, yang diatur dalam Undang-undang. Ketentuan konstitusi diatas merupakan pengakuan mutlak negara kepada masyarakat adat yang secara mutatismutandis negara wajib memberikan perlindungan yaikni perlindungan dari aspek ekonomi, sosoial, politik bahkan sampai pada setiap dimensi kehidupan masyarakat adat di wilayah pesisir Negara Kesatuan Republik Indonesia.

Jawahir Thontowi dalam Cornelis Van Vollenhoven yaitu keseluruhan aturan tingkah laku positif yang di satu pihak mempunyai sanksi (hukum) dan dipihak lain dalam keadaan tidak dikodifikasi (adat). Tingkah laku positif memiliki makna hukum yang dinyatakan berlaku di sini dan sekarang.sangsi disini lebih menekan pada reaksi dari pihak lain atas pelanggaran terhadap suatu norma hukum. ${ }^{16}$

Hukum adat merupakan hukum asli masyarakat Indonesia sehingga yang tidak tertulis dalam bentuk perundang-undangan Republik Indonesia yang di sana-sini mengandung unsur keagamaan dan magis serta kongkrit selalu mengedepan titah raja yang berlaku pada suatu desa karena titah raja secara langsung menjelma dlam kehidupan masyarakat adat tersebut. UU Cipta Kerja (Omnisbus Law) telah disahkan dan memberikan perubahan pada tatanan kehidupan masyarakat Indonesia secara 
menyeluruh karna suatu naskah hukum yang baik harus memiliki kaidah-kaidah social dan norma agama yang beralaku diindonesia tanpa harus menyampingkan kehidupan masyarakat adat.

Suatu konstitusi atau hukum dasar yang benar-benar hidup dalam masyarakat tidak hanya terdiri dari naskah yang tertulis akan tetapi juga meliputi konvensikonvensi. Undang-Undang Dasar 1945 menganut paham ini dan selalu dapat mengikuti perkembangan zaman karena UUD tersebut selain dapat dilakukan perubahan, revisi juga penyempurnaan sebagaimana kedudukan hukum adat dengan jelas diakui keberadaan dalam hukum dasar diIndonesia.

Aktualisasi dari penerapan UU Cipta Kerja (Omnisbus Law) akan dipahami secara tuntas oleh masyarakat hukum adat yang berada diwilayah pesisir ataukah berdampak terhadap hak-hak kepemilikan masyarakat hukum adat baik yang berda didarat maupun dilaut yang akan di gunakan untuk kepentingan bisnis para investor oleh sebab itu perlu ada sebuah tindakan pencegahan yang dilakukan karena dalam pasal 18 B Ayat (2) undang-undang dasar yang diamendemen berbunyi : " Negara mengakui dan menghormati kesatuan-kesatuan masyarakat hukum adat beserta hakhak tradisionalnya sepanjang masih hidup dan sesuai dengan perkembangan masyarakat dan prinsip negara kesatuan repoblik indonesia.

Sementara Pasal 3 ayat (2) Undang-Undang Nomor 4 tahun 2004 yang menyatakan bahwa: "pengadilan negara menetapkan dan menegakan hukum dan rasa keadilan berdasarkan Pancasila". Sesuai dengan bunyi Pasal 18 B Ayat (2) Undang-Undang Dasar dan Pasal 3 ayat (2) Undang-Undang Nomor 4 tahun 2004 Negara harus melindungi masyarakat hukum adat dengan menegakan keadilan yang seadil-adilnya karena masyarakat hukum adat merupakan warga negara indonesia yang diakui berdasarkan Undang-Undang Dasar 1945.

Masyarakat maluku merupakan komponen masyarakat hukum adat yang sudah terbentuk jauh serbelum negara merdeka dan merupakan masyarakat yang hidup pada wilayah pesisir karena kehidupan mereka sejak dulu kala sudah menjadikan laut sebagai tempat untuk memberikan kehidupan bagi mereka dan untuk membenarkan hal tersebut secara khusus untuk wilayah Provinsi Maluku lewat Peraturan Daerah pasal 5 Perda Nomor 14 tahun 2006, yang berbunyi : “untuk ditetapkan kembali menjadi negeri atau yang disebut dengan nama lain, maka kesatuan masyarakat hukum adat tersebut harus memenuhi persyarat yang terdiri:

a) Unsur masyarakat adat;

b) Unsur wilayah yang jelas;

c) Unsur institusi adat;

d) Unsur hubungan masyarakat dengan wilayah;

e) Unsur lembaga-lembaga social;

f) Unsur symbol adat;

g) Unsur perilaku adat;

h) Unsur lain sesuai dengan adat istiadat dan budaya dari masyarakat setempat.

Untuk memberikan penjelasan bahwa unsur masyarakat adat yaitu terdapatnya sekelompok orang yang masih terikat oleh tatanan hukum adatnya baik karena factor 
genelogis maupun genealogisnya maupun territorial sebagai warga bersama suatu kesatuan masyarakat adat tertentu dan mengakui serta menerapkan ketentuanketentuan hukum adat dalam kehidupannya sehari-hari.

Unsur-unsur inilah yang saling berhubungan satu dengan yang lain guna memperkuat tatanan kehidupan masyarakat adat, struktur kelembagaan adat, perakat sosial kemasyarakatan yang dijamin berdasarkan konstitusi untuk wajib dilindungi oleh negara beserta hak-hak yang melekat pada masyarakat adat. Selanjutnya ketentuan dalam Pasal 14 Undang-undang Cipta Kerja yang bermetode Omnibus Law ayat (1) berbunyi perencanaan tata ruang dilakukan untuk menghasilkan :
a) rencana umum tata ruang dan
b) rencana rinci tata ruang
c) Pada ayat (2) yang berbunyi :
d) rencana tata ruang wilayah nasional
e) rencana tata ruang wilayah provinsi dan
a) rencana tata ruang wilayah kota

Pada ayat (3) rencana rinci tata ruang sebagaimana dimaksud pada ayat (1) huruf $\mathrm{b}$ terdiri atas :

a) rencana tata ruang pulau/kepulauan dan rencana tata ruang kawasan strategis nasional; dan

b) rencana detail tata ruang kabupaten/kota.

Selanjutnya ayat (4) rinci tata ruang sebagaimana dimaksud pada ayat (1) huruf $\mathrm{b}$ disusun sebagai perangkat operasional rencana umum tata ruang. Ayat (5) rencana tata ruang sebagaimana dimaksud pada ayat (3) huruf a disusun apabila:

a) rencana tata ruang belum dapat dijadikan dasar dalam pelaksanaan pemanfaatan ruang dan pengendalian pemanfaatan ruang, dan/atau

b) rencana umum tata ruang yang mencakup wilayah perencanaan yang luas dan skala peta dalam perencanaan umum tata ruang tersebut memerlukan perencian sebelum dioperesionalkan.

Penegasan pada Pasal 14 UU Omnibus Law pada ayat (1),(2),(3),(4) yang menjelaskan tentang perencanaan tata ruang wilayah yang strategis guna penggunaan dan pemanfaatan ruang wilayah tersebut untuk pembangunan dan menjalankan bisnis pemerintah sudah tentu menjadi ancaman tersendiri bagi masyarakat adat yang hidup pada wilayah pesisir karna kawasan laut dan darat (hutan/petuanan) mereka akan digunakan untuk kepentingan negara karena kawasan laut dan darat termasuk dalam rencana umum tata ruang kawasan strategis nasioanl.

Provinsi maluku sebagai wilayah kepulauan dimana wilayah laut lebih besar daripada daratan yang sebagian besar wilayah tersebut terdapat hak kepemilikan masyarakat adat pesisir tersebut sehingga permasalahan vital pada hak masyarakat adat yang berada pada wilayah pesisir maka kehidupan masyarakat adat dengan sendirinya akan terdistorsi dalam kaitannya dengan regulasi dan penganturannya dalam negara indonesia.

Syarifudin berpendapat bahwa ditinjau dari latar belakang sejarah maka masyarakat hukum adat Indonesia,memiliki kebudayaan yang sudah sangat tua dan 
jauh lebih tua dari terbentuknya kerajaan atau Negara. Sehingga, warga masyarakat hukum adat di Indonesia serta etnik yang melingkupi, sesungguhnya merupakan migran dari kawasan lainnya di Asia Tenggara. Secara kultural mereka termasuk dalam kawasan Austronesia, yaitu budaya petani sawah, dengan tatanan masyarakat serta hak kepemilikan yang ditata kolektif, khususnya hak kepemilikan atas tanah ulayat. Dalam kehidupan politik, beberapa etnik berhasil mendominasi etnik lain beserta wilayahnya, dan membentuk kerajaan-kerajaan tradisional, baik yang berukuran lokal maupun yang berukuran regional. ${ }^{14}$

Pengaturan terkait masyarakat hukum adat bersifat abadi yang memiliki kekuasaan atas wilayah darat dan laut bersifat abadi sehingga pengaturan hukum berkaitan dengan masyarakat hukum adat harus mendapat jaminan oleh pemerintah. Begitu banyak konflik yang terjadi dimaluku antara masyarakat adat dengan pemerintah berkaitan dengan hak ulayat mereka dikuasai oleh perusahan yang menjalankan usahanya pada bidang pertambangan dan hak pengelolaan hutan (hph) sehingga masyarakat adat pada wilayah pesisir merasa tidak berdaya karena berhadapan dengan pihak perusahan yang dibeking langsung oleh para TNI/POLRI yang ditugaskan langsung untuk mengawal para investor tersebut.

Masyarakat adat pesisir dimaluku yang sering terjadi konflik dengan pihak perusahan seperti di pulau romang Kabupaten MBD terdapat perusahan Gemala Borneo Utama yang melakukan eksploitasi pertambangan emas dimulai dari 2016 -2018 memicu konflik dengan masyarakat adat pulau romang mereka melakukan aksi penolakan kepada pemerintah Provinsi Maluku agar dapat mencabut ijin perusahan pertambangan emas tersebut karena hak ulayat masyarakat adat pulau romang telah dikuasai oleh perusahan.

Masyarakat adat desa arma, watmuri, tutukembung dan manglusi Kabupaten Kepulauan Tanimbar sebagaian hak ulayat mereka dikuasai oleh perusahaan sehingga menuai konflik antara masyarakat adat dan perusahan yang mendapat ijin resmi dari pemerintah untuk hak penguasaan hutan sehingga dalam menjalnkan bisnis kayu menerobos masuk kewilayah petuanan masyarakat adat secara brutal bisnis mereka berjalan mulus hingga saat ini karena mereka dikawal langsung oleh polisi sehingga masyarakat adat tidak berdaya hanya menerima dampak lingkungan dari akibat penebangan kayu. beranjak dari kasus-kasus konflik masyarakat adat pesisir dengan perusahan kiranya menjadi perhatian kusus oleh negara dalam memberikan perlindungan terhadap masyarakat adat pesisir yang ada diwilayah maluku.

Menurut Iin Indarti bahwa Masyarakat pesisir adalah sekumpulan manusia yang hidup bersama-sama mendiami wilayah pesisir, membentuk dan memiliki kebudayaan yang khas yang terkait dengan ketergantungan pada pemanfaatan sumberdaya dan lingkungan pesisir Wilayah pesisir merupakan sebuah kawasan dinamis yang sangat strategis untuk mengembangkan berbagai sektor usaha.Tetapi sayangnya program pemberdayaan masyarakat nelayan di wilayah pesisir belumlah tergarap secara proposional. Pemanfaatn sumber daya kelautan belumdi'managed" 
secara tepat guna, yang semakin diperparah timbulnya konflik-konflik kepentingan. ${ }^{14}$ Masyarakat adat pada wilayah pesisir bukan tameng pemerintah dalam menerima berbagai dampak tetapi harus diberdayakan dan harus didasarkan pada tiga aspek meliputi :

1) Kekuatan kelembagaan social dan ekonomi masyarakat pesisir serta kemampuan pengelolaan sumberdaya yang berkelanjutan.

2) Pemerintah memberikan kesempatan dan jaminan legal formal.

3) Pihak swasta termasuk pengusaha pengusaha yang terkait dalam wadah kerjasama yang menguntungkan nelayan yang didukung dengan infrastruktur yang memadai.

\section{P E N U T U P}

Berdasarkan seluruh pemaparan diatas maka penulis dapat menyimpulkan bahwa UU Cipta Lapangan Kerja yang bermetode Omnibus law ini adalah kemudahan perizinan, menghapus dan mengubah beberapa pasal dan ayat yang ada pada UU Nomor 26 tahun 2007 tentang Penataan Ruang, UU Nomor 27 Tahun 2007 tentang Pengelolaan Wilayah Pesisir dan Pulau-Pulau Kecil, UU Nomor 32 tahun 2014 tentang Kelautan dan UU Nomor 4 Tahun 2011 tentang Informasi Geospasial yang pada intinya adalah pengalihan sebagian besar kewenangan pemerintah daerah baik Provinsi, Kabupaten dan kota pada satu pintu yaitu pemerintah pusat kiranya dampak memberikan dampak yang positif bagi masyarakat adat yang berada pada wilayah pesisir. Perlindungan hukum oleh negara kepada Masyarakat Adat merupakan upaya untuk menjamin dan melindungi Masyarakat Adat beserta haknya agar dapat hidup tumbuh dan berkembang sesuai dengan harkat dan martabat kemanusiannya. Letak atau esensi dari hukum adalah untuk melindungi kepentingan rakyat dengan memberikan keadilan, kebebasan menentukan pilihan, perlakuan yang adil, perlakuan yang manusiawi, serta memberikan hak-hak masyarakat untuk memperoleh kesejahteraan dan pekerjaan yang layak, termasuk yang bermuatan penegakan hukum. Diberlakukannya undang-undang Omnibus Law yang bermetode cipta kerja kiranya dapat memberikan solusi bagi masyarakat adat pesisir dalam pengelolaan sumberdaya alam secara berkelanjutan.

\section{REFERENSI}

Asshiddiqie, Jimly. Hukum Tata Negara Dan Pilar Demokrasi, Serpihan Pemikiran Hukum Dan HAM. Jakarta: Konstitusi Press, 2005.

Asshiddiqie, Jimly. Pengantar Ilmu Hukum Tata Negara. Jakarta: Rajawali Pers, 2014.

Fahmal, H. A. Muin. Peran Asas-Asas Umum Pemerintahan Yang Layak Dalam Mewujudkan Pemerintahan Yang Bersih,. Yogyakarta: UII Press, 2006.

Ibrahim, Johni. Teori Dan Metodologi Penelitian Hukum Normatif. Malang: Bayumedia Publishing, 2007.

14 Iin Indarti and Yeni Kuntari, "Model Pemberdayaan Sumberdaya Masyarakat Pesisir Melalui Re-Enggenering Ekonomi Berbasis Koperasi Berkelanjutan," in Kajian Multi Disiplin Ilmu Untuk Mewujudkan Poros Maritim Dalam Pembangunan Ekonomi Berbasis Kesejahteraan Rakyat, 2015. 
Indarti, Iin, and Yeni Kuntari. "Model Pemberdayaan Sumberdaya Masyarakat Pesisir Melalui Re-Enggenering Ekonomi Berbasis Koperasi Berkelanjutan." In Kajian Multi Disiplin Ilmu Untuk Mewujudkan Poros Maritim Dalam Pembangunan Ekonomi Berbasis Kesejahteraan Rakyat, 2015.

Kansil, C.S.T. Pengantar Ilmu Hukum Dan Tata Hukum Indonesia. Jakarta: Balai Pustaka, 1980.

MD, Mahfud. Membangun Politik Hukum, Menegakkan Konstitusi. Jakarta: Rajawali Pers, 2011.

MD, Mahfud. Politik Hukum Di Indonesia. Jakarta: Rajawali Pers, 2010.

Pound, Roscoe. An Introduction to the Philosophy of Law. Terjemahan. Jakarta: Bhatara Niaga Media, 1996.

Ridwan HR. Hukum Administrasi Negara. Jakarta: Raja Grafindo Persada, 2018.

Soekanto, Soeryono. Faktor-Faktor Yang Mempengaruhi Penegakan Hukum. Jakarta: Raja Grafindo Persada, 2008. 